\title{
OUDITIEWE AANDAG BY DIE VOORSKOOLSE KIND
}

\author{
ELMARIE NIEMAND M.A. (LOG.) (PRET.) \\ Departement Spraakwetenskap, Spraakheelkunde en Oudiologie, Universiteit van \\ Pretoria.
}

\section{OPSOMMING}

Daar is met hierdie navorsingsprojek gepoog om 'n duidelike beeld te vorm van ouditiewe aandagsprosessering by die voorskoolse kind.

Aangesien ouditiewe aandagsprosessering van groot belang is vir die kind wat skool toe gaan is daar op dié groep wat in die daaropvolgende jaar skool toe gaan besluit. 'n Groep van 64 kinders is geselekteer. Daar is gebruik gemaak van 'n gegradeerde ouditiefgerigte ondersoekprogram wat só saamgestel is dat dit wetenskaplik verantwoordbaar is.

In sy geheel gesien dui die navorsingsresultate daarop dat die basiese ontwikkelingsproses van ouditiewe aandagsprosessering op hierdie ouderdom $(5 ; 2$ tot $5 ; 8)$ voltooi is. 'n Verdere evaluering van dieresultate in terme van die uiteengesette doelstellings van die navorsingsprojek dui daarop dat kinders in hierdie ouderdomsgroep nog soms moeite ondervind om aan' $n$ ouditiewe sei binne omgewingslawaai aandag te skenk. Bekende seine verhoog die vermoë om aandag te skenk. Daar kon egter nie vir alle aannames wat in die literatuur gemaak word, bewys gevind word nie.

\section{SUMMARY}

The object of this research project is to establish a clear picture of the process of auditory attention of the pre-school child.

The immense importance of the process of auditory attention for the school-age child guided the decision to use a group of children qualifying for school in the following year. A group of 64 children was selected. A scientifically acceptable graded auditory research programme was used.

In general, the research results indicate that the basic development of the process of auditory attention has been completed at the age of $5 ; 2$ to $5 ; 8$. A further evaluation indicates that some children, however, still have difficulty in attending to an auditory stimulus in the presence of background noise. Known stimuli tend to improve the ability to pay attention. All claims in the literature could not be accounted for.

Aandag is die aspek van ouditiewe persepsie wat waarskynlik met die totale proses van ouditiewe persepsie verband hou. ${ }^{13}$ 'n Studie in dié veld sal dus van waarde wees wanneer daar na oplossings gesoek word vir vraagstukke wat direk met ouditiewe persepsie en dus ook ouditiewe aandag in verband staan. Die belang van aandag word ook deur Lewis ${ }^{19}$ beklemtoon deur sy beskouing dat aandag nie slegs verband hou met ouditiewe persepsie nie, maar dat die toetsing van aandagsvermoëns ook van waarde kan wees by die identifikasie van kortikale betrokkenheid en patologie.

Wanneer daar gepoog word om ouditiewe aandag te definieer is dit moontlik'om hedendaagse beskouings in een omvattende definisie te vervat vanweë die groot mate van oorvleueling wat voorkom. So 'n definisie kan soos volg lui: die funksie van aandag is om instelling van die organisme ten opsigte van die sein te verbeter aangesien dit lei tot 
aktiewe gemoeidheid met die sein. Deur die proses van aandag word inligting verkry deur die inkomende stimuli te filtreer en dan te bepaal watter gedeelte van die inkomende stimuli die sentrale prosesseerder in beslag sal neem op 'n gegewe oomblik. Relevante inligting word dus uit die omgewing geselekteer en geprosesseer.

In die literatuur word ook begrippe gevind wat baie nou verwant is aan aandag en ook in baie gevalle aandag impliseer. Hierdie begrippe is konsentrasie, waaksaamheid, seleksie, soektog, aktivering en instelling. ${ }^{9}$ Dit is dus duidelik dat aandag nie stereotiep van aard is nie, maar dat dit ' $n$ integrale deel van die persepsieproses is. Dit lei tot die verwagting dat daar verskillende vorms van aandag sal wees.

Die verskillende vorms van aandag sluit primêre aandag; sekondêre aandag; tersiêre aandag; aktiewe aandag; passiewe aandag; eksterne, interne, sensoriese en begripsvormende aandag; vernoude aandag; ${ }^{12}$ selektiewe aandag; ${ }^{20}$ fokusaandag ${ }^{5}$ en ewewigtige aandag in. Wat veral hier van belang is, is dat die verskillende vorms van aandag, behalwe vir tersiêre, passiewe en ewewigtige aandag, ook tot 'n mindere of meerdere mate oor 'n selektiewe eienskap beskik.

Hierdie verwantskap wat onderling bestaan, dui ook daarop dat daar waarskynlik spesifieke eienskappe gevind word wanneer die proses van aandag ontleed word. Die eienskappe van aandag betrek kontrole, ${ }^{14}$ die leerproses, ${ }^{18}$ die inkomende sein, ${ }^{21}$ die wakkertoestand, ${ }^{16}$ verskillende modaliteite, ${ }^{2}$ konsentrasie, persoonlikheid, ${ }^{12}$ die sekondêre stimulus, ${ }^{22}$ persepsie en integrasie. Hieruit kan die belang van aandag as deel van die totale persepsieproses afgelei word.

'n Ander aspek wat van belang is, maar tot nog toe baie min aandag geniet het, is die ontwikkeling van aandag. Die waarde van die beperkte inligting tot die leser se beskikking lê daarin dat dit aandui dat die kind op 'n skoolgaande ouderdom oor 'n goed ontwikkelde ouditiewe prosesseringsisteem beskik.

Daar is verskillende benaderings tot die aspek van aandag waarvan die mees aanvaarbare waarskynlik die neuro-psigologiese benadering ${ }^{23}$ is aangesien die rol van die sentrale sisteem ook in berekening gebring word.

Die doel van hierdie studie is om 'n beeld te vorm van ouditiewe aandagsprosessering soos gepresenteer deur die normale voorskoolse kind.

\section{EKSPERIMENT}

\section{DOELSTELLINGS}

\section{Doelstellings met betrekking tot maskeringsvariante}

Die eerste doel van die eksperiment is om te bepaal of kinders, net voordat hulle skool toe gaan, wel aandag kan skenk aan 'n ouditiewe sein in die teenwoordigheid van omgewingslawaai.

'n Tweede doel is om te bepaal of maskering by die normale kind tot gevolg sal hê dat daar 'n verskerping in aandag sal wees. 
'n Derde doel is daarop gemik om vas te stel of daar 'n betekenisvolle verskil tussen maskering deur middel van wyebandgeraas (pienkruis) en maskering deur middel van 'n roesemoes van stemme bestaan. Dit sal dus van akademiese waarde wees om hierdie aspek by die navorsing in te sluit.

\section{Doelstellings met betrekking tot die sein}

Die eerste doel is om vas te stel of ' $n$ meer betekenisvolle sein, byvoorbeeld 'n klokkie of 'n trom, makliker aandag ontlok en behou as 'n nie-betekenisvolle sein, byvoorbeeld 'n suiwertoon $(500 \mathrm{~Hz}$ of $4000 \mathrm{~Hz}$ ).

'n Tweede doel is om te bepaal of daar 'n verskil gemaak word tussen klankseine en spraakseine wat betref die mate waarin daar aandag daaraan geskenk word.

'n Derde doel het te doen met 'n belangrike aspek, naamlik bekendheid wat deur Yusson et $\mathbf{a l}^{24}$ beklemtoon word. Binne dieselfde subtoets word gebruik gemaak van 'n bekende sein (trom) teenoor 'n onbekende sein (suiwertoon: $500 \mathrm{~Hz}$ ).

\section{Doelstellings met betrekking tot intensiteit}

Die doel hier is om te bepaal of dit wel so is dat harder klanke of te wel seine met 'n hoër intensiteit makliker aandag trek as klanke wat net op die gehoordrempel val.

4. Doelstellings met betrekking tot die intensiteitsverhouding tussen die maskering en die sein

Die doel van die eksperiment sal ook wees om te bepaal of daar beduidende verskille voorkom by die vermoë om aandag te skenk indien die maskeringslawaai harder as die sein is, gelyk aan die sein is, of sagter as die sein is.

5. Doelstellings met betrekking tot die kompleksiteit van die toetsmateriaal

Die doel hier sal wees om te bepaal of kompleksiteit van die toetsmateriaal 'n invloed uitoefen op die ouditiewe aandagsvermoë van die jong kind. Volgens Johnson en Toppino ${ }^{8}$ en Jordaan et $\mathrm{al}^{9}$ bestaan daar by die jong kind die neiging om voorkeur te gee aan minder komplekse seine. Die eksperiment sal dus gegradeer word. Daar sal aanvanklik slegs van die proefpersoon verwag word om aandag te skenk aan 'n klanksein en 'n spraaksein te midde van maskering. Daarna word die opdrag meer kompleks deurdat visuele komponente (voorwerpe en prente) ook geïnkorporeer word en die ouditiewe sein by die visuele sein gepas moet word. Hierna word die opdrag verder gekompliseer deurdat van die proefpersoon verwag word om die spraaksein te identifiseer en te reproduseer. Die laaste opdrag vereis prosessering van die boodskap asook 'n motoriese handeling na aanleiding van die geprosesseerde boodskap. 
6. Doelstellings met betrekking tot geslag

'n Verdere doel van die eksperiment sal wees om te bepaal of daar enige verskille bestaan tussen seuns en dogters van die ouderdom $5 ; 2$ tot $5 ; 8$ wat betref ouditiewe aandagsvermoë.

\section{Doelstellings met betrekking tot gedragspatrone}

Die doel hier is om gedragspatrone waar te neem wat kan dien om die resultate verder toe te lig. Aspekte wat hier in ag geneem word is verveling, 'n algemene onvermoë om sekere toetsitems te bemeester, die nodigheid om bo en behalwe die aanvanklike opdrag ook tussenin met die proefpersoon te kommunikeer om motivering te versterk en reaksietyd.

\section{PROEFPERSONE}

Kriteria vir die seleksie van proefpersone

Seleksie het volgens die volgende kriteria geskied: Om 'n verteenwoordigende beeld van die ouditiewe aandagsvermoëns van die proefpersone te verkry, was dit nodig dat seleksie só sal geskied, dat elke area van die stadsgebied van Pretoria verteenwoordiging sal geniet.

Daar is in oorleg met 'n statistikus besluit om 100 proefpersone te selekteer.

Die ondersoek word só gerig dat die vermoë om aandag te skenk direk gekoppel word aan die klaskamersituasie. Die proefpersone is dus so geselekteer dat dit die groep wat die daaropvolgende jaar toegelaat word tot graad I, betrek. Hierdie groep is ook verder geskik vir seleksie aangesien daar aangeneem kan word dat die proses van ouditiewe aandagsprosessering reeds op hiérdie ouderdom $(5 ; 2$ tot $5 ; 8)$ ten volle ontwikkel is. ${ }^{17}$

Die moontlikheid van 'n psigo-neurologiese disfunksie moes uitgegeskakel word aangesien ondervinding in die praktyk geleer het dat kinders wat as sódanig geklassifiseer word, meesal leerprobleme presenteer en ook aandagsprobleme ondervind. So 'n proefpersoon sal dus nie geskik wees vir dié studie nie.

Die proefpersone moet ook oor 'n normale intelligensie beskik aangesien dit nie bekend is in hoe ' $n$ mate 'n subnormale intelligensie die aandagsvermoë van die kind sal beïnvloed nie.

Die selfhandhawing van die proefpersoon is ook van belang aangesien 'n infantiele emosionele toestand die eksperimentele prosedure nadelig sal beïnvloed.

Die mediese geskiedenis van die proefpersoon moet ook in ag geneem word aangesien aspekte soos epilepsie, ${ }^{6}$ medikasie, ${ }^{1}$ gedurige oorinfeksies en mangelinfeksies ' $n$ belangrike rol speel in die afname van die aandagsvermoë.

Dit is ook belangrik dat die proefpersone oor 'n normale gehoorvermoë beskik aangesien die eksperiment ouditief aangebied word.

Aangesien die verskille, indien enige, tussen seuns en dogters met betrekking tot ouditiewe aandag bepaal moet word, moet die seleksie 
van proefpersone sodanig wees dat albei geslagte verteenwoordig word. Aangesien die literatuur nie besliste onderskeid maak met betrekking tot geslag nie, is seuns en dogters op 'n toevallige basis geselekteer.

Die seleksie van proefpersone

Die proefpersone is geselekteer uit verskeie kleuterskole binne die stadsarea van Pretoria. Daar is op kleuterskole besluit vir die volgende redes:

- proefpersone is makliker bekombaar;

- 'n meer betroubare beeld met betrekking tot, byvoorbeeld, intelligensie, sosiale aanpasbaarheid, ensovoorts, kan verkry word deur middel van vraelyste wat onderskeidelik deur die ouers en die onderwyseres voltooi moes word;

- 'n verteenwoordigende monster van die populasie van Pretoria word so verseker.

Om te verseker dat die hele stadsgebied van Pretoria ingesluit word, is die stad in 5 blokke verdeel waaruit 2 kleuterskole elk geselekteer is. Daar is bepaal dat die groep wat in die daaropvolgende jaar (1980, in die geval van dié navorsing) skool toe sou gaan tussen die ouderdomme $5 ; 2$ tot $5 ; 8$ val. Alle kinders by die 10 kleuterskole in hierdie ouderdomsgroep is aanvanklik in die navorsing ingesluit as potensiële proefpersone.

Om 'n oorsigtelike beeld van die kind se algemene ontwikkeling, intelligensie, emosionele ryping, gedrag, aandagsvermoë en mediese geskiedenis te verkry, is afsonderlike vraelyste aan beide die kleuterskoolonderwyseres en ouers vir voltooiing gegee. Hierdie vraelyste moes dien om proefpersone wat nie vir hierdie studie geskik is nie, te identifiseer, byvoorbeeld 'n geskiedenis van leerprobleme in die familie.

Die vraelyste is ook so opgestel dat belangrike aspekte, soos byvoorbeeld intelligensie op beide vraelyste voorkom sodat daar ook 'n mate van kontrole tussen die twee vraelyste is.

Nadat die gegewens verkry uit die vraelyste gekontroleer is, is moontlike proefpersone geselekteer. Hierdie proefpersone is onderwerp aan identifikasie-oudiometrie ${ }^{11}$ om te bepaal of hulle oor normale gehoor beskik. Hierdie siftingstoetse is by die kleuterskole uitgevoer waar die lokaal só gekies is dat omgewingslawaai sodanig beperk is dat ' $n$ normaalhorende persoon die toetstoon wel by $20 \mathrm{~dB}$ hoor. 7

Alle kinders wat ook oor 'n normale gehoor beskik is hierna ingesluit as proefpersone in die eksperiment. Daar is uiteindelik van 64 proefpersone gebruik gemaak; 32 seuns en 32 dogters.

\section{MATERIAAL EN APPARAAT}

Hier kan 'n tweeledige verdeling gemaak word, naamlik eerstens, die apparaat en materiaal wat van toepassing was by die seleksie van die 
proefpersone en tweedens, apparaat en materiaal wat betrekking het op die eksperiment self.

1. Materiaal en apparaat vir die seleksie van proefpersone

\section{Vraelyste}

Twee vraelyste is saamgestel: een vir voltooiing deur die ouers en 'n tweede vir voltooiing deur die onderwyseresse.

Gehoorsifting

Hier is gebruik gemaak van 'n draagbare Madsen-oudiometer, model OB 40 (ISO, 1964).

2. Materiaal en apparaat vir die uitvoer van die eksperiment Maskering

By die keuse van maskering is dit nodig om die aspek van integrasie in gedagte te hou. Dit word as belangrik beskou aangesien die parameters van die sein beïnvloed kan word en dus 'n verkeerdelike of onewe beeld kan gee. Daar is besluit op pienkruis omdat dit 'n breë spektrum het en op 'n roesemoes van stemme aangesien dit baie nou verband hou met die omgewingslawaai wat in die klaskamersituasie gevind word.

\section{Toetsmateriaal}

Die toets is in 5 subtoetse verdeel. In die eerste 4 subtoetse is gebruik gemaak van klank of spraakseine wat kontrasteer deurdat dit hoofsaaklik hoë of lae frekwensies betrek. Die 5e subtoets behels verbale opdragte.

\section{Samestelling van die Toetsmateriaal en Maskering}

Dit is met die hulp van die Wetenskaplike Navorsing en Nywerheidse Raad (WNNR) (Departement Akoestiek) saamgestel. Die maskering en die stimulussein is so vermeng dat die sein en die maskering eerstens gelyk is aan mekaar, daarna is die sein $10 \mathrm{~dB}$ sagter as die maskering en in die laaste instansie, $10 \mathrm{~dB}$ hoër as die maskering. Elke subtoets is 12 keer herhaal.

TABEL I: 'n Voorstelling van die vermenging van die stimulussein en die maskering

\begin{tabular}{|c|c|c|c|c|}
\hline & \multicolumn{2}{|c|}{$40 \mathrm{~dB}$ bo die gehoordrempel } & \multicolumn{2}{|c|}{ Op die gehoordrempel } \\
\hline & Pien & Stemme & ruis & Stemme \\
\hline Sein in $\mathrm{dB}$ & $-10-20 \quad 0$ & $-10-20: 0$ & $\begin{array}{lll}-10 & -20 & 0\end{array}$ & $-10-20 \quad 0$ \\
\hline $\begin{array}{l}\text { Maskering in } \\
\text { klankdrukpeil }\end{array}$ & $-10-10-10$ & $-10-10-10$ & $-10-10-10$ & $-10-10-10$ \\
\hline
\end{tabular}


Die rede vir die herhaling van die pienkruis en die stemme is dat die eksperiment eers $40 \mathrm{~dB}$ bo die gehoordrempel $(60 \mathrm{~dB})$ uitgevoer word, en daarna op die gehoordrempel $(20 \mathrm{~dB}$ - na aanleiding van die gehoorsifting) om te bepaal of 'n verhoogde intensiteit aandagsvermoë verbeter.

Die tydsintervalle tussen elke toetsitem is vooraf ewekansig geselekteer en tydens die opname by die WNNR met behulp van 'n stophorlosie gekontroleer.

Daar is ook 'n kalibrasiesein op die band aangebring sodat dit gekoppel kan word aan 'n oudiometer en die nodige verstellings (van $60 \mathrm{~dB}$ na $20 \mathrm{~dB}$ ) met behulp van die oudiometer gedoen kan word.

\section{Apparaat}

Die apparaat wat uiteindelik in die eksperiment gebruik is, is 'n Nagra IV-bandmasjien, 'n oopspoelband waarop die toetsmateriaal is, 'n Maico MA 24-oudiometer (ISO, 1964), oorfone en twee aangrensende klankdigte lokale. Die bandmasjien is aan die oudiometer gekoppel en sodoende kon die toets binouraal en streng gekontroleerd aangebied word.

Addisionele apparaat is gebruik tydens subtoets 3 waar die proefpersoon die voorwerp of prent moes uitwys. Vir dié doel is 'n trom, 'n klokkie en prente van 'n wiel en 'n bad op 'n tafeltjie voor die proefpersoon geplaas. Die volgorde waarin die items geplaas is, was sodanig dat dit nie dieselfde volgorde is waarin die sein aangebied word nie.

Daar is deurgaans gepoog om in soverre dit moontlik was die eksperiment so saam te stel dat dit verantwoordbaar was in terme van wetenskaplike akkuraatheid.

\section{EKSPERIMENTELE PROSEDURE}

Die Nagra-bandmasjien is aan die oudiometer gekoppel. Die oudiometer is met behulp van die kalibrasiesein op die band gekalibreer (VU-meterlesing $=0$ ) sodat lesings op die oudiometer werklike lesings sou wees. Elke subtoets is deur die opdrag, wat deur die toetsafnemer direk gegee is, voorafgegaan. Daarna is die subkategorie as 'n geheel eers teen $60 \mathrm{~dB}$ en dan teen $20 \mathrm{~dB}$ aangebied. Daar is besluit dat die eksperiment binouraal aangebied gaan word aangesien dit die alledaagse situasie beter verteenwoordig as ' $n$ monourale sein. ${ }^{3}$ Dit sluit ook die aspek van lateraliteit uit, met ander woorde, dat in die geval van 'n digotiese luistertaak, die boodskap in die regteroor meer akkuraat weergegee word. ${ }^{15}$

Proefpersone is indiwidueel gesien. Die toets is aaneenlopend aangebied en geen pouse is gemaak tussen subtoetse nie. Uitputting is voorkom deurdat opdragte voor elke subtoets gegee is en sodoende word die toets onderbreek. Tydsintervalle tussen die items van die subtoetse word gevarieer om te verseker dat daar nie 'n reaksiepatroon vasgelê word nie, byvoorbeeld sein ( 3 sek.) sein ( 3 sek.) sein. 'n Aspek 


\begin{tabular}{|c|c|c|c|c|c|c|c|}
\hline \multirow{11}{*}{ 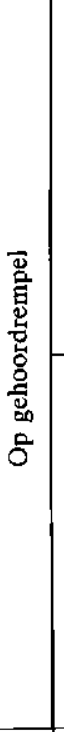 } & \multirow{5}{*}{ 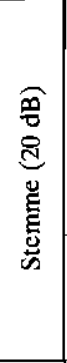 } & $\begin{array}{l}\text { 号 } \\
\text { 品 }\end{array}$ & 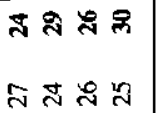 & 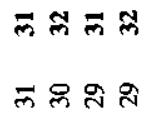 & 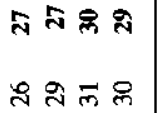 & 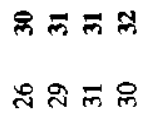 & 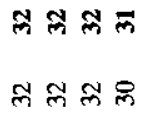 \\
\hline & & $\infty$ & 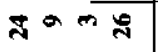 & গু ল্ন ম & ñd & $19-1$ & 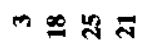 \\
\hline & & 9 & $\stackrel{\infty}{\infty}$ in $\tilde{a}$ & 규 & 욤ㅁㅁ & $|\infty N|$ & n \\
\hline & & $\infty$ & సి జి సి & $\overline{ल े} \bar{ल} \bar{m}$ & 隶 & 쥬 & 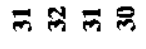 \\
\hline & & స్ & $\sim \approx \infty \approx$ & প్ల প్ల ని & 志 志望 & - సి ని & 요 స్లు స్ల \\
\hline & \multirow{6}{*}{ 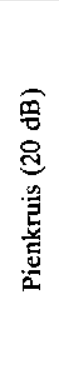 } & $\stackrel{9}{7}$ & జ & స్ల ల్ల స ల్ల & 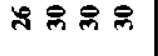 & קల జి లె లి & స్ల స్ల స్ల $\bar{m}$ \\
\hline & & 扁 & 요 సి & 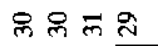 & స్లల్లేల & ని స్ ల్లు & స్ల స్ల స్ల \\
\hline & & 囯 & & 류 & 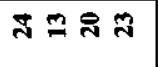 & $-\infty-6$ & 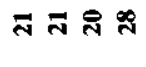 \\
\hline & & 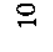 & $\pi \cong n \pi$ & $\approx \widetilde{N} \sim \mathbb{N}$ & $9=\pi \pi$ & $- \pm 1 n$ & $9 \vec{N} \pm N$ \\
\hline & & 啚 & 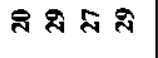 & లెల్లన్ల & 더류 정 & స & $\bar{m} \bar{m} \boldsymbol{m}$ \\
\hline & & గి & 궈 $\infty$ & లెల్ల & 육 & $\simeq \approx \approx \simeq$ & $\bar{m} \approx \bar{N}$ \\
\hline \multirow{9}{*}{ 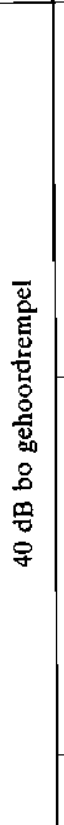 } & \multirow{5}{*}{ 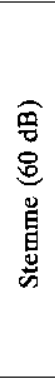 } & $\frac{9}{8}$ & & స్లుల్లు & $\mathbb{N} \approx \tilde{N} \bar{n}$ & 두 శ్ శ్ & N \\
\hline & & 2 & 요 & 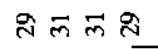 & స & ニミㅛ & $\bar{m} \bar{m} \bar{m}$ \\
\hline & & 曲 & 5 & జి లి స్ల & มి ส๖ & $--\pi$ & 1100 \\
\hline & & ำ & సింలి స్ & సి & $2 \pi$ & $|\sim| 1$ & $111 N$ \\
\hline & & $\begin{array}{l}\text { 9 } \\
8 \\
8\end{array}$ & 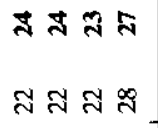 & 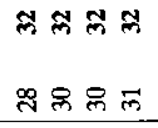 & 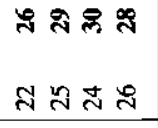 & 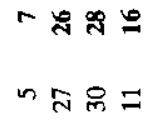 & $\begin{array}{l}\text { पूస స్లె స్లా } \\
\text { ్లస్ స్ }\end{array}$ \\
\hline & \multirow{3}{*}{ 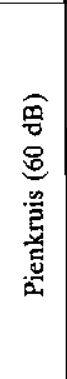 } & 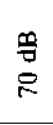 & 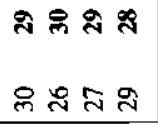 & 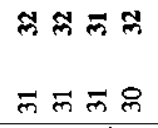 & 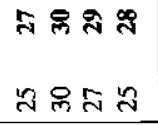 & 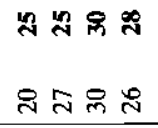 & 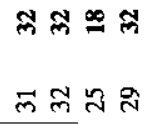 \\
\hline & & $\begin{array}{l}\frac{0}{8} \\
\stackrel{8}{n}\end{array}$ & 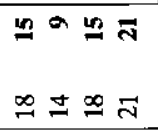 & 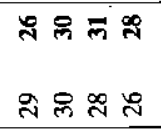 & $\begin{array}{l}\simeq 9 \simeq 9 \\
\simeq \sim \pm \infty\end{array}$ & $\begin{array}{l}m \subseteq m- \\
-\infty \infty\end{array}$ & $\begin{array}{l}m \infty 6= \\
m \infty n \Xi\end{array}$ \\
\hline & & $\begin{array}{l}\text { \% } \\
8 \\
8\end{array}$ & 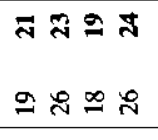 & 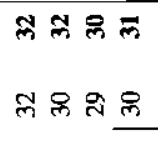 & 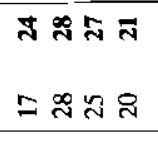 & $\begin{array}{l}\infty \pi \pm a \\
\stackrel{a}{=} g \infty\end{array}$ & $\begin{array}{l}=4 n \\
==0 \%\end{array}$ \\
\hline & 亗 & 漹 & $\pi n m \theta$ & $\rightarrow N m \sigma$ & $\operatorname{rnm}$ & $-\operatorname{sen}$ & An 4h \\
\hline & 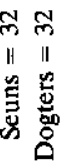 & 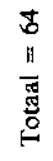 & 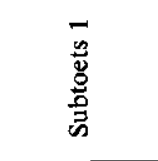 & 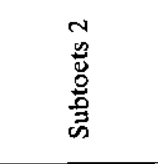 & 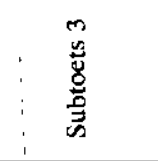 & 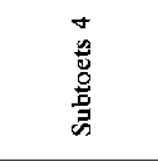 & 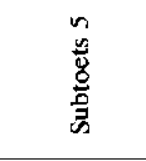 \\
\hline
\end{tabular}


wat nie gekontroleer is nie, is die feit dat toetsitems altyd in dieselfde volgorde aangebied is en die moontlikheid van leer nie uitgeskakel word nie.

Daar is in 'n klankdigte kamer gewerk en aangesien dit vir 'n kind bedreigend kan wees, is ' $n$ ouer toegelaat om by die proefpersoon te sit tydens die eksperiment. Die ouers is so geplaas dat hy/sy buite die gesigsveld van die proefpersoon was om te voorkom dat die proefpersoon se aandag afgetrek word.

Alvorens die toetsafnemer na die aangrensende klänkdigte kamer gegaan het, is die prosedure van die eksperiment aan die proefpersoon verduidelik. Daar is ook aan die proefpersoon gevra om die voorwerpe en prente op die tafel te identifiseer om te verseker dat die proefpersoon daarmee vertroud is. Hierdie voorbereidende prosedure is as belangrik beskou aangesien daar goeie rapport met die kind opgebou moes word. Daar moes ook verseker word dat die proefpersoon die prosedure van die eksperiment goed verstaan.

Soos reeds genoem is die opdragte vir die verskillende subtoetse direk gegee en is dit nie op die band geplaas nie. Dit was om die toetsafnemer die geleentheid te gee om kontak met die proefpersoon te behou. Dit is belangrik aangesien daar van voorskoolse kinders gebruik gemaak is.

'n Toetsvorm is opgestel en die reaksies van die proefpersone is as korrek $(\sqrt{ })$ of foutief $(\mathrm{X})$ aangedui. Hierdie gegewens is in Tabel II weergegee.

\section{RESULTATE}

Die ontleding van die resultate is gedoen met behulp van die tegniek van regressie-analise met skynveranderlikes. 'n Samevattende beeld van die resultate word in Tabel III weergegee.

Uit hierdie resultate kan die volgende afgelei word:

Aspekte wat ouditiewe aandagsprosessering nie beïnvloed nie

Daar is slegs 3 aspekte wat deurgaans geen verandering in die respons van die proefpersone meebring nie. Hierdie aspekte is:

- die aanbieding van die toetsmateriaal op die gehoordrempel;

- die wisselwerking tussen die sein en maskering waar die sein en die maskering gelyk is aan mekaar;

- geslag.

Aspekte wat die vermoë om aandag te skenk laat afneem

Hier is 6 aspekte betrokke. Die afleiding kan dus gemaak word dat daar tog op hierdie ouderdom $(5 ; 2$ tot $5 ; 8)$ aspekte is wat ouditiewe aandagsprosessering bemoeilik. Hierdie aspekte is:

- die seine wat hoofsaaklik lae frekwensies betrek;

— 'n hoë frekwensiesein, asook die opdrag "vryf jou neus"; 


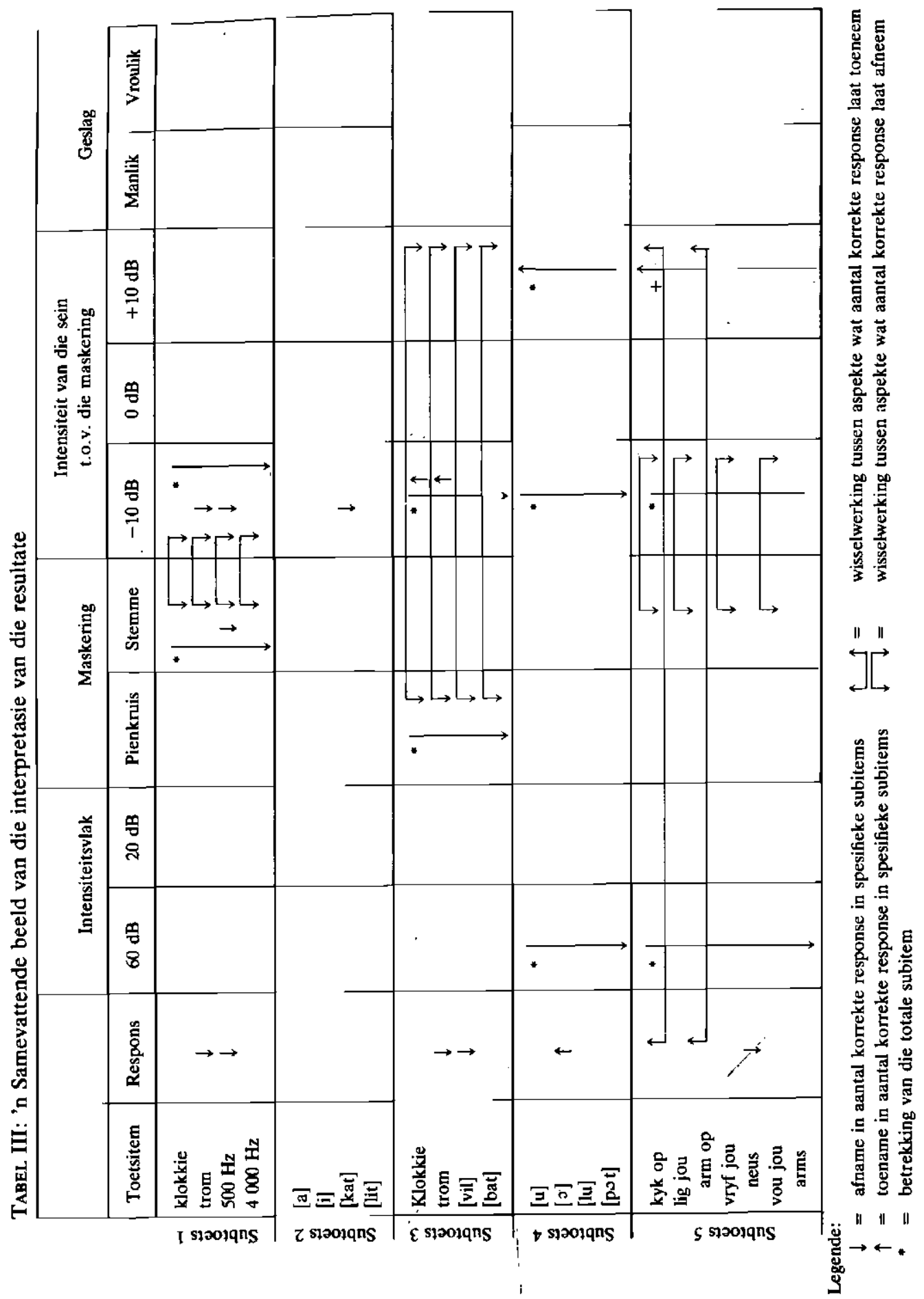

The South African Journal of Communication Disorders, Vol. 27, 1980 
- wanneer die toetsitems en maskering $40 \mathrm{~dB}$ bo die gehoordrempel (wat vir die studie as $20 \mathrm{~dB}$ aangeneem is) aangebied word en die proefpersoon die toetsitem moet herhaal of 'n motoriese opdrag moet uitvoer na aanleiding van die sein;

- pienkruis as maskering wanneer klankseine sowel as spraakseine gebruik word; hierdie invloed word verder vergroot indien dit in wisselwerking met ' $n$ sein teen $+10 \mathrm{~dB}$ ten opsigte van die maskering is;

- stemme as maskering waar slegs van klankseine gebruik gemaak word;

- 'n wisselwerking tussen stemme as maskering en die sein teen $-10 \mathrm{~dB}$ ten opsigte van die maskering by klankseine sowel as verbale opdragte;

- die aanbieding van die sein teen $-10 \mathrm{~dB}$ ten opsigte van die maskering.

Aspekte wat die vermoë om aandag te skenk laat toeneem

Die aspekte wat hier aangedui word, is soos volg:

- die aanbieding van die sein teen $+10 \mathrm{~dB}$ ten opsigte van maskering in die subtoetse waar die sein herhaal moes word en waar 'n motoriese handeling uitgevoer moes word na aanleiding van die sein;

- $/ \mathrm{O} /$ as sein by die verbale herhaling waarskynlik omdat dit die enigste betekenisvolle klank is.

Met hierdie resultate beskikbaar kan die oorspronklike doelstellings in oënskou geneem word en die resultate kan daarop van toepassing gemaak word.

BESPREKING VAN DIE RESULTATE AAN DIE HAND VAN DIE DOELSTELLINGS

Die invloed van maskering

Dit wil uit die resultate voorkom asof maskering wel aandag beïnloed en dit skyn asof kinders van die ouderdom $5 ; 2$ tot $5 ; 8$ nog nie in alle gevalle kan aandag skenk in die teenwoordigheid van omgewingslawaai nie. Wanneer van klankseine as stimulus gebruik gemaak word beïnvloed stemme as maskering die response sodanig dat 'n betekenisvolle afname in korrekte response waargeneem is. Sodra daar ook 'n visuele sein bygevoeg word en die stimulussein beide uit klanke en spraak bestaan, verlaag pienkruis die aantal korrekte response betekenisvol. Hier is ook gevind dat maskering in wisselwerking met die aanbieding van die sein teen $-10 \mathrm{~dB}$ en $+10 \mathrm{~dB}$ ten opsigte van die maskering die aantal korrekte response betekenisvol laat afneem. Hier is dus heelwat teenstrydighede. Die afleiding wat gemaak kan word, is dat omgewingslawaai wel op hierdie ouderdom $(5 ; 2$ tot $5 ; 8)$ nog ' $n$ invloed uitoefen. Daar is egter heelwat gevalle waar dit nie betekenisvolle invloed uitoefen nie. Indien Northern en Downs ${ }^{17}$ se aanname dat die ouditiewe sisteem se ontwikkeling op 4;0 voltooi is, 
waar is, en Luria, ${ }^{10}$ Simon, ${ }^{21}$ en andere, se aannames dat daar 'n verdere verfyning van die ontwikkeling plaasvind ook aanvaar kan word, sou gesê kon word dat die vermoë om aandag te skenk binne 'n omgewingslawaai waarskynlik deel van die verfyningsproses is, aangesien die groep kinders wat gebruik is in die ouderdomsgroep $5 ; 2$ tot $5 ; 8$ val.

Daar kon nie enige bewys gevind word in die geval van hierdie ouderdomsgroep $(5 ; 2$ tot $5 ; 8)$, vir die bewering van Jordaan et $a^{9}$ dat maskering aandag verskerp nie. Geen verskil kon gevind word tussen die gebruik van pienkruis en stemme as maskering nie.

\section{Die invloed van die sein}

Daar kon geen bewys gevind word dat meer betekenisvolle seine, byvoorbeeld 'n klokkie of 'n trom teenoor suiwertone, 'n beter respons tot gevolg het nie. Dit wil dus voorkom asof betekenis nie meer op hierdie ouderdom $(5 ; 2$ tot $5 ; 8)$ vir die herkenning van seine belangrik is nie.

Dit blyk ook dat daar nie onderskeid gemaak word tussen klank en spraakseine nie. Frekwensie speel wel in 'n mate 'n rol aangesien daar swakker respons verkry is op lae frekwensieseine as in die geval van hoë frekwensieseine.

Die bekendheid met die stimulus is 'n aspek wat wel die vermoë om aandag te skenk beïnvloed. Die feit dat subtoets 2 so min inligting verskaf, word toegeskryf aan die aspek van bekendheid. Daar word slegs van die proefpersone verwag om 'n vrouestem ten opsigte van maskering te herken, en daarop te reageer. Hulle word daagliks aan 'n vrouestem (kleuterskoolonderwyseres) blootgestel en dit is dus baie bekend aan hulle. In subtoets 3 vaar die proefpersone betekenisvol swakker waar die woord /vil/ as stimulus gebruik word teenoor die woord $/ \mathrm{bat} /$. In die alledaagse lewe is die proefpersone waarskynlik meer blootgestel aan die woord / bat/ as die woord /vil/, angesien die woord /bat/' $n$ huishoudelike woord is. In subtoets 4 is daar 'n betekenisvolle verbetering in die antal korrekte response by die aanbieding van die spraakklank $/ \%$. Daar word in die kleuterskole gebruik gemaak van die geluide wat diere maak en $/ \mathfrak{o} /$ is die klank wat aan 'n vark verbind word. Dit is waarskynlik waarom die proefpersone so goed daarop reageer. ' $n$ Verdere aspek wat daarop dui dat bekendheid met die stimulus belangrik is, is die feit dat alle opdragte in subtoets 5 behalwe die opdrag "vryf jou neus" waarskynlik bekend is aan die proefpersone. Hulle vaar dan ook betekenisvol swakker wanneer die opdrag "vryf jou neus" aangebied word.

Die invloed van die intensiteit van die aanbieding

Daar word gevind dat daar 'n betekenisvolle afname in respons voorkom by subtoetse 4 en 5 , waar net van spraakseine gebruik gemaak is, wanneer hierdie seine teen $60 \mathrm{~dB}$ aangebied word. Dit is belangrik om in gedagte te hou dat die maskering ook teen $60 \mathrm{~dB}$ 
aangebied is, en dus die reaksie van die proefpersone mag beïnvloed: Daar is egter geen bewys gevind vir die stelling van Jordaan et al ${ }^{9}$ dat seine met 'n hoër intensiteit makliker aandag trek as seine wat op die gehoordrempel val nie.

Die invloed van die intensiteitsverhouding tussen die maskering en die

\section{sein}

Hier blyk dit deurgaans dat indien die stimulussein $10 \mathrm{~dB}$ swakker as die maskering is, daar 'n betekenisvolle afname in die aantal korrekte response van die proefpersone is. 'n Verdere aspek wat 'n afname teweegbring is die wisselwerking tussen die aanbieding van die sein teen $-10 \mathrm{~dB}$ ten opsigte van die maskering en die gebruik van 'n roesemoes van stemme as maskering.

Sodra die sein $10 \mathrm{~dB}$ bo die maskering aangebied word, is daar 'n betekenisvolle verbetering in die aantal korrekte response van die proefpersone en wel met betrekking tot spraakseine.

Hierdie resultate moet in ag geneem word wanneer kinders wat in hierdie ouderdomsgroep $(5 ; 2$ tot $5 ; 8)$ val, blootgestel word aan konvensionele sein-tot-ruistoetse. Dit behoort interessant te wees om die resultate van súlke toetse te vergelyk met die resultate van hierdie studie.

\section{Die invloed van die kompleksiteit van die toetsmateriaal}

Daar kon geen bewys gevind word vir die feit dat meer komplekse seine aandagsvermoëns beïnvloed nie. By die bespreking van die opstel van die eksperimentele materiaal is genoem dat daar gegradeer is wat betref die moeilikheidswaarde van die toetsmateriaal. Indien kompleksiteit wel 'n rol speel sou die verwagting dus wees dat die aantal korrekte response moet afneem namate die toets vorder. Dit het egter nie gebeur nie en vandaar die afleiding dat dit geen invloed uitoefen nie. Die moontlikheid dat die moeilikheidswaarde nie genoegsaam gegradeer is nie, kan nie uitgeskakel word nie.

Die rol van geslag

Hier kon deurgaans geen verskille gevind word nie en dit blyk dus dat dit geen invloed uitoefen op aandagsvermoëns van die kind op die ouderdom $5 ; 2$ tot $5 ; 8$ nie.

Die waarneming van gedragspatrone wat die resultate mag beïnvloed Hierdie waarnemings is tydens toetsing gedoen en 'n aantekening is gemaak wanneer enige gedragspatroon voorgekom het wat die toetsresultate mag beïnvloed.

Daar is slegs in twee gevalle verveling opgemerk. Die proefpersone het verder deurgaans stil gesit en aandagtig geluister na die opdrag en daarna na die stimuli. Daar is gepoog om die duur van die toets te beperk om verveling uit te skakel. Dit blyk geslaagd te wees.

Geeneen van die gekose toetsitems was te gekompliseerd nie en 
opdragte is ook dadelik begryp. Die moeilikheidswaarde blyk dus ook nie 'n faktor te wees wat die resultate kon beïnvloed nie.

Dit was met die jonger groep $(5 ; 2)$ soms nodig om met die oorskakeling van die aanbieding teen $60 \mathrm{~dB}$ na $20 \mathrm{~dB}$ 'n bietjie aanmoediging te gee in die vorm van verbale beloning. Dit was veral tussen die aanbiedings van toetse 4 en 5 nodig. Dit was egter nie deurgaans gedoen nie en slegs wanneer dit wou voorkom asof daar 'n algemene afname in motivering was.

Geeneen van die proefpersone het moeite ondervind om te reageer binne die tydperke wat daargestel was nie. Die tydperk gelaat tussen die verskillende items van die subtoetse was dus heeltemal voldoende.

\section{GEVOLGTREKKINGS}

Uit die literatuur het dit geblyk dat die aspek van ouditiewe aandagsvermoëns op die ouderdom van 4;0 sodanig ontwikkel is, dat daar slegs verdere verfyning van die bestaande prosesse voorkom tussen die ouderdomme $5 ; 0$ tot $14 ; 0 .{ }^{17,19}$

Wanneer die resultate verkry uit die eksperiment van hierdie studie aan dié stelling gemeet word kan die stelling aanvaar word, mits die invloed wat maskering op aandag uitoefen beskou word as ' $n$ verdere verfyning van die proses. Daar is egter nie deurgaans gevind dat maskering in alle gevalle die vermoë om aandag te skenk nadelig beïnvloed nie aangesien sommige proefpersone wel goed gereageer het ten spyte van die maskering. Daarom word 'n verdere afleiding gemaak dat, indien dit 'n verfyningsproses is, nie alle kinders op skoolgaande ouderdom hierdeur beïnvloed sal word nie. Hierdie is dan ook waarskynlik 'n aspek wat aandag moet geniet wanneer besluite aangaande skoolrypheid geneem moet word. Daar sal bepaal moet word of die kind wel kan aandag skenk binne 'n omgewingslawaai aangesien dit 'n belangrike element is vanweë die hoë peil van omgewingslawaai in die klaskamer van verál die jonger groepe ( $\mathrm{Gr}$ i en Gr ii). ${ }^{19}$

Op die ouderdom 5;2 tot 5;8 is die kind ook nog baie aangewys op die bekendheid van die materiaal waarna geluister word. Hierdie vermoë om aandag te skenk aan relatief minder bekende seine is dus waarskynlik ook deel van die verfyningsproses. Dit is weer eens 'n aspek waarna opgelet moet word wanneer besin word oor die feit dat die kind skoolgereed is, al dan nie, aangesien daar ' $n$ ' groot blootstelling aan onbekende stimuli binne die klaskamersituasie is.

'n Aspek wat deurgaans aandagsvermoëns nadelig beïnvloed het, was wanneer die sein $10 \mathrm{~dB}$ swakker as die maskering was. Dit is 'n belangrike waarneming met betrekking tot voorligting aan die onderwyser(es) van die jonger groep in die skool (Gr i). Daar sal beslis deurgaans probleme ondervind word deur die kinders om aandag te skenk aan 'n stimulus te midde van omgewingslawaai en dít moet in gedagte gehou word tydens onderrig of aanbieding van veral onbekende of nuwe materiaal. 
Hierdie gegewens is ook belangrik vir die oudioloog aangesien dit die response op sein-tot-ruistoetse definitief sal beïnvloed. Response op só 'n toets kan dus nie as betroubaar beskou word nie.

Opsommend kan dus gesê word dat die ontwikkelingsproses van ouditiewe aandag by die groep $5 ; 2$ tot $5 ; 8$ voldoende is om aan die eise wat binne die formele onderrigsituasie gestel word, te voldoen. Wanneer daar dus 'n leerprobleem opgemerk word, sal dit ook belangrik wees om ondersoek in te stel na die ontwikkeling van ouditiewe aandagsvermoëns.

Ouditiewe aandagsprosessering verdien 'n regmatige plek in navorsingstudies en behoort ook as 'n belangrike aspek gereken te word wanneer die jong kind 'n probleem, byvoorbeeld 'n vertraagde taalontwikkeling, presenteer:

In childhood the delay in language acquisition, poverty, or inarticulate oral expression, difficulty in responding to oral instructions, apparent difficulty in appreciating the sequence of oral instruction, and difficulty in sound localization would suggest central dysfunction. If these manifestations represent an absence of function when they should be present, a developmental origin should be suspected and when there is a decline in these functions which are described to have been previously present, acquired central nervous system disorder should be suspected. ${ }^{4}$

As ouditiewe aandag beskou word as ' $n$ integrale deel van ouditiewe persepsie is dit ook dus 'n sentrale proses en kan kennis daaromtrent van groot diagnostiese waarde wees.

\section{DANKBETUIGINGS}

Mev $S R$ Hugo en mnr HE C Tesner, Departement Spraakwetenskap, Spraakheelkunde en Oudiologie, Universiteit van Pretoria, vir hulle hulp gedurende die studie.

Prof D J Stoker, Hoof van die Departement Statistiek, Universiteit van Pretoria, vir die statistiese ontledings van die resultate. Mnr P Meffert, Departement Akoestiek, WNNR, vir die tegniese samestelling van die toetsmateriaal.

\section{VERWYSINGS}

1. Botha, D. (Red) (76/77): Summarized Outlines on the Pharmacology of Important Drug Groups. MIMS Desk Reference, 12, 26-31.

2. Caplan, L. R. (1978): Variability of Perceptual Functioning: The Sensory Cortex as a "Categorizer" and "Deducer". Brain and Language, 6, 1-13.

3. Carhart, R. (1967): Binaural Reception of Meaningful Material. In: A. B. Graham Sensorineural Hearing Processes and Disorders. Little, Brown and Company, Massachusetts. 
4. Duane, D. D. 1977: Central Auditory Dysfunction in: Keith, R. $A$ neurologic Perspective of Central Auditory Dysfunction. Grune \& Stratton N.Y.

5. Fox, J. (1974): Recognition and Attention. Quarterly Journal of Experimental Psychology, 26, 144-157.

6. Guyton, A. C. (1966): Function of the Human Body. W. B. Saunders Company, Philadelphia.

7. Johnson, D. J. \& Myklebust, H. R. (1967): Learning Disabilities: Educational Principles and Practices. Grune and Stratton, N.Y.

8. Johnson, P. J. et al (1974): Effects of Category Attention, Relative Frequency of Relevant Values and Practice on Attribute Identification Performance. Journal of Experimental Psychology, 103, 160-166.

9. Jordaan, W. J. et al (1975): Algemene Sielkunde: 'n Psigobiologiese Benadering. McGraw-Hill, Johannesburg.

10. Luria, A. R. (1973): The Working Brain: An Introduction to Neuropsychology. The Penguin Press, Allen Lane.

11. Martin, M. (1978): Retention of Attended and Unattended Auditorily and Visually Presented Material. Quarterly Journal of Experimental Psychology, 30, 187-200.

12. Meldman, M. J. (1970): Diseases of Attention and Perception. Pergamon Press, N.Y.

13. Moray, N. (1969): Attention: Selective Processes in Vision and Hearing. Hutchinson Educational, London.

14. Moray, N. et al (1976): Attention to Pure Tone. Quarterly Journal of Experimental Psychology, 28, 271-283.

15. Myers, T. F. (1970): Asymmetry and Attention in Phonic Decoding. In: Sanders, A. F. (Red). Attenion and Performance III: proceedings of a symposium on attention and performance. North-Holland Publishing Company, Amsterdam.

16. Neisser, U. (1967): Cognitive Psychology. Meridith Publishing Company, N.Y.

17. Northern, J. L. \& Downs, M. P. (1974): Hearing in Children. The Williams and Wilkins Company, Maryland.

18. Rydberg, S. \& Arnberg, P. W. (1976): Attending and Processing Broadened within Children's Concept Learning. Journal of Experimental Child Psychology, 22, 161-177.

19. Saunders, D. A. (1977): AuditoryPerception of Speech: An Introduction to Principles and Problems. Prentice Hall, N.Y.

20. Shiffrin, R. M. et al (1976): Attending to Fourty-Nine Spatial Positions at once. Journal of Experimental Psychology: Human Perception and Performance, 2, 14-22.

21. Simon, H. A. (1972): On the Development of the Processor: In: Farnham-Diggory, S. (Red). Information Processing in Children. Academic Press, N.Y.

22. Underwood, G. (1977): Attention, Awareness and Hemispheric Differences in Word Recognition. Neuropsychologia, 15, 61-67. 
23. Walley, R. E. \& Weiden, T. D. (1973): Lateral Inhibition and Cognitive Masking: A Neuropsychological Theory of Attention. Psychological Review, 80, 284-302.

24. Yusson, S. R. \& Levy, V. M. (Jnr.) (1975): Effects of Warm and Neutral Models on the Attention of Observational Learners. Journal of Experimental Child Psychology, 20, 66-72. 


\section{Aids for}

- the development of perception

- the acquisition of speech and language skills

- the improvement of motor co-ordination

\section{Plus}

- helpful texts for therapists

- educational toys, books and equipment

- records for auditory training

- catalogues on request

- large variety of tests available

\section{Stockists of}

- Learning to Listen

- Two sound lottos

- "Listen what is that?"

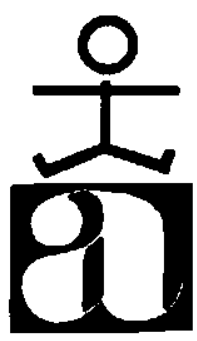

\section{PLAY AND SCHOOLROOM}

8 Tyrwhitt Avenue, Rosebank (adjoining the Constantia Cinema)

Telephones: 788-1304

P.O. Box 52137, Saxonwold, 2132 